\title{
Dividend Policy and Share Price volatility: Evidence From Pakistan Stock Exchange of Listed Commercial Banks
}

\author{
Laeeq Ahmad (Corresponding Author) \\ Hailey College of Commerce, University of the Punjab Lahore, Pakistan \\ E-mail: Laeeqhcc771@gmail.com \\ Yasir Iftikhar \\ National College of Business Administration \& Economics, Pakistan
}

Sarmad Ejaz

Hailey College of Commerce, University of the Punjab Lahore, Pakistan

Waqas Baig

Hailey College of Commerce, University of the Punjab Lahore, Pakistan

Kashif Nadeem

National University of Modern Languages Lahore Campus

Ms. Rabia Shahid

Hailey College of Commerce, University of the Punjab Lahore, Pakistan

Received: March 13, 2019 Accepted: May 9, 2019 Published: May 11, 2019

doi:10.5296/ieb.v5i1.14769

URL: https://doi.org/10.5296/ieb.v5i1.14769 


\section{Abstract}

This study examines the all possible dividend policy effect on commercial banks stock price listed at Pakistan stock exchange. The study covers 17 listed commercial banks for the time period 2014 to 2017. To analyze secondary data multiple regression analysis was applied using Stata with the model (MP) Market Price Per Share as the dependent variable and (EPS) Earning Per Share, (ROE) Return on Equity, (RR) Retention Ratio and (DY) Dividend Yield are independent variables. Descriptive statistics were applied to data to check mean, median, maximum and minimum value. The finding of the study shows that EPS shows a highly significant positive impact on the share MP and the other three independent variable return on equity, dividend yields, and retention ratio also show a significant but negative impact on the share MP. These results support the finding of previous studies done by another researcher in the past.

Keywords: Dividend Policy (DP), Retention Ratio (RR), Return on Equity (ROE), Earning per Share (EPS), Cash Dividend, Market Price per Share (MP)

\section{Introduction}

This topic is widely researched topic in finance and investment field that how firm share market price is affected by firm dividend payout policy decisions, but still, it is a mystery that whether the stock prices of firms are affected with firm's dividend policy or not. Some research suggests that firm dividend policy is irrelevant to its share market price (1961; "MM"). Dividend policy refers to a company's policy which indicates that what proportion of earning should be distributed and what proportion of earning should be retained for gaining a reinvestment opportunity. To answer this question manager must concentrate on what type of dividend policy should be adopted and what type of policy will lead toward maximization of shareholders wealth.

Purchasing corporate stock is a desired of investor and popular investment activity (Amidu \& Abor, 2006). All type of investor could see media report for the evaluation of stock prices. The share price is a healthy indicator and best predictor whether the investors invest in particular stock or not. To gain a high level of return at low risk is the primary objective of investment. Many other factors contribute to the price changes. These factors include investors' overreactions to earnings, news, and signal of optimism and pessimism (Shiller, 1989). When rumors spread among public they will affect the price of shares. However, it is difficult to adopt the smooth pattern of stock returns over the different calendar periods (Michaely, Thaler, \& Womack, 1995). It is difficult to predict the value of a share on the base of the economic system(Lee, Liu, Roll, \& Subrahmanyam, 2006). It is because some other factors influence the price of shares (Cutler et al., 1989).

The dividend payment is an important element for shareholders. Dividend paid by a company understands a good sign for investor and tells about that company adopts the rules and practices (Jo \& Pan, 2009). Rules and practices attract the investor and raise funds from the capital market. When investor attracts toward companies share the share price of the company will be increased. The increase in share price causes an increase in profit.

Dividend payments behavior of a firm is also very important for an investor to make an investment decision. Payout ratio of dividend can affect company market value in both 
directions like positively or adversely (Elfakhani \& Chaudhury, 1995). Many factors can affect the dividend policy of firms like dividend payment constraint, available investment opportunities and other alternative sources of capital for the firms (Fida et al., 2012).

The study on dividend policy conducted by Miller and Modigliani (1961; "MM"). This study is benchmarked for another researcher that guide the manager in setting up the company payout policy. He says that the association between dividend policy and stock price volatility does not exist. He also argues that the dividend paid or not the firm's value remains irrelevant. In reality, investor pay tax on dividend and he did not want to pay tax on the capital gain. The investor pays taxes only when they sold their shares. A company who does not pay a dividend is attractive for the investor as compared to those who do pay (Black, 1976). Resultantly, those companies who did not pay a dividend the stock price of such companies would be increased.

\subsection{Research Questions}

Is there a relationship between return on equity and average price per share?

Is there a relationship between earning per share and the average price per share?

Is there a relationship between retention ration and the average price per share?

Is there a relationship between dividend yield and the average price per share?

\subsection{Literature Review}

The topic of dividend policy has been a point of convergence more than half-century (Gordon, 1959; Modigliani, 1982; Okafor \& Chijoke-Mgbame, 2011). In financial literature dividend policy is an issue of interest for the researcher since the company's structure changed and the businessman starts to build joint stock companies. Dividend policy connotes to the payout policy, which managers pursue in deciding the size and pattern of cash distribution to shareholder's overtime (Jones \& Williams, 1999). Gittman (2004) divided the firm stock into preferred and common stock and also showed that share dividends are the outcome of the investment. In today, dividend policy has gone beyond this scope whether the dividend is paid or not. Such other issues are considered how to create equilibrium between highly taxed and untaxed investor, how to maintain and raise the value of the share.

Fluctuating stock usually measured to trace risk and represent the fluctuating in price. If stock considered volatile, its price may differ with the passage of time and it is difficult to forecast about this type of stock. The investor wants to invest in a stock that is less risky. The less risky investment considered the best investment (Kinder, 2002).

Several studies conducted to explain the relationship between dividend policy and stock price volatility. The study reveals that there is a negative relationship between stock price volatility and dividend yield (Baskin, 1989). These results indicate that the firm with higher dividend yields will cause lower risk. Similar results strengthen the argument of Baskin by Chijoke Mgbame, Hussainey, and Oscar Mgbame (2011) in his study from 1998 to 2007 of the UK firms. Many studies have been conducted in Pakistan belong to this issue. (Nazir, n.d., p. 2010) from 2003 to 2008 using data of 73 firms on the KSE and results show that the relationship between dividend yield and stock price volatility exist. Another study shows the relationship between stock price volatility and dividend policy. But this relationship is negative between these two variables Noreen (2016). But another study shows a positive 
relation between stock price volatility and dividend Hamid et al. (2017).

Many studies conducted on the relationship between dividend and share price volatility (Allen \& Rachim, 1996). Also, there are many theories that explain the relationship between dividend and stock price volatility included birds in hands theory, clientele effect, and signaling theory.

\subsection{Theories of Dividend Policy}

In the area of finance, dividend policy has been considered a powerful argument. Evidence can be found in numerous studies related to dividend policy from(Lintner, 1956) to(Miller, 2002; Modigliani, 1982) to (Bhattacharya, 1979) and more recently (DeAngelo, DeAngelo, \& Skinner, 1996) (Fama \& French, 2001), (Nizar Al Malkawi, 2007) (Nizar Al-Malkawi, 2007). Some other theories are below related to dividend policy.

\subsection{Irrelevance Theory of Dividends}

The most comprehensive argument about irrelevance theory of dividend is presented by Miller and Modigliani(1961). They argue that dividend policy is an irrelevance and it has no effect on the price of the share. The main assumption of this theory is to pay $100 \%$ dividend by management. The remaining assumptions of MM theory follow. 1) There is a perfect capital market. Taxes will not be implementing and a single buyer cannot influence the market. 2) Investors are rational and there are no flotation costs. 3) The investment policy of a firm does not change and new investment will not change the business risk. 4) Dividends can be forecast with certainty by Investors.

\subsection{Bird in Hand Theory}

Nizar Al Malkawi (2007) states that current dividend payment reduces uncertainty because the future is uncertain. The dividend has more value than capital gain. Due to uncertainty investor will prefer to receive dividend rather than to gain an opportunity of reinvestment. There are some assumptions of this theory and the crux of this theory is; investors have an idea about firm regarding profitability and the tax rate higher on cash dividend. Also, those cash flows can be predicted on the base of the dividend. Management paid a dividend to send a positive message about firms' financial position although they know about the tax disadvantage of paying a dividend.

\subsection{Agency Cost and Free Cash Flow Theory}

The cost occurs between the conflict of management and shareholders Ross et al (2008). Management performs work for own benefit rather than shareholders. Miller and Modigliani (1961) state that a manager must work on behalf of shareholders. There is a difference between management and owners. Managers' activities could be costly for the shareholders just like as to undertake unprofitable investments Malkawi (2007). Such cost bears by shareholders instead of management. The conflict occurs between shareholders and bondholders because shareholders demand more dividend than bondholders. Easterbrook (1984) identifies two agency cost; the cost of risk aversion and the second cost is to the monitoring of managers.

\subsection{Signaling Theory}

MM states that managers and investors have knowledge about the firm. Management has more information about firm than an investor and it is opposed by many researchers. 
Therefore, the investor thinks different about firm and gaps create between managers and investors. Managers pay a dividend to shareholders to convey private information and in this way, the manager will be able to fill this gap (Nizar Al \&Malkawi, 2007). Amount of dividend which is paid an investor to carry great information about firm Pettit (1972). Increase in dividend shows a good sign and brighter prospects of the firm. Managers are reluctant to reduce dividend it pays a dividend only when it has a trust that profit increased Lintner (1956).

\subsection{Clientele Effect of Dividend Theory}

Investors want to invest in a preferred share of the company because this type of stock satisfies a particular need. That's why investor faces different tax slab rate and sometimes bears transaction cost at the time of purchasing and selling securities. Modigliani and Miller (1961) argue that investors have attention towards firms and these firms give rewards to investors in this way cost to be minimized. They also argue that the clientele effect may change a dividend policy because every investor desires a different level of dividends and in this way dividend policy becomes irrelevant. Those firms who move toward growth pay less dividend would attract an investor to appreciate your capital, while those firms who move toward their maturity they give a dividend to attract the clientele Al-Malkawi (2007). Clientele effect could be dividing into two grouped, first who think about tax effect and second who thinks about transactional cost Al-Malkawi (2007).

\section{Conceptual Model and Hypotheses}

\subsection{Definition of Variables}

The market price of the share was taken as the dependent variable and independent variables are Dividend yield, retention ratio, return on equity and earnings per share. It is expected that all the variables of our study have a significant effect on the stock price.

\subsection{Market Price (MP)}

This is our dependent variable which is the average share price of the share in a year average price was calculated by taking the average of low and high market prices of the share.

\subsection{Dividend Yield (DY)}

Dividend yield shows us that how much dividend paid by a company to its shareholder in relation to share price. The dividend yield is calculated by dividing the dividend on the share price at that time. The dividend yield is an important variable because it has an effect on stock price

\subsection{Retention Ratio (RR)}

Retention Ratio shows us that how much of its earning company retains it is opposite of company dividend payout ratio and calculated by subtracting total paid dividend amount from earning available for the common stockholder and dividing the remaining amount with total earning available for common stockholders

\subsection{Earnings per Share (EPS)}

EPS is earnings per each outstanding share of a company and calculated by dividing earnings available for common stockholder by no of share outstanding. 


\subsection{Return on Equity (ROE)}

ROE is calculated by dividing the amount of PAT (Profit after tax) with the amount of shareholders' equity.

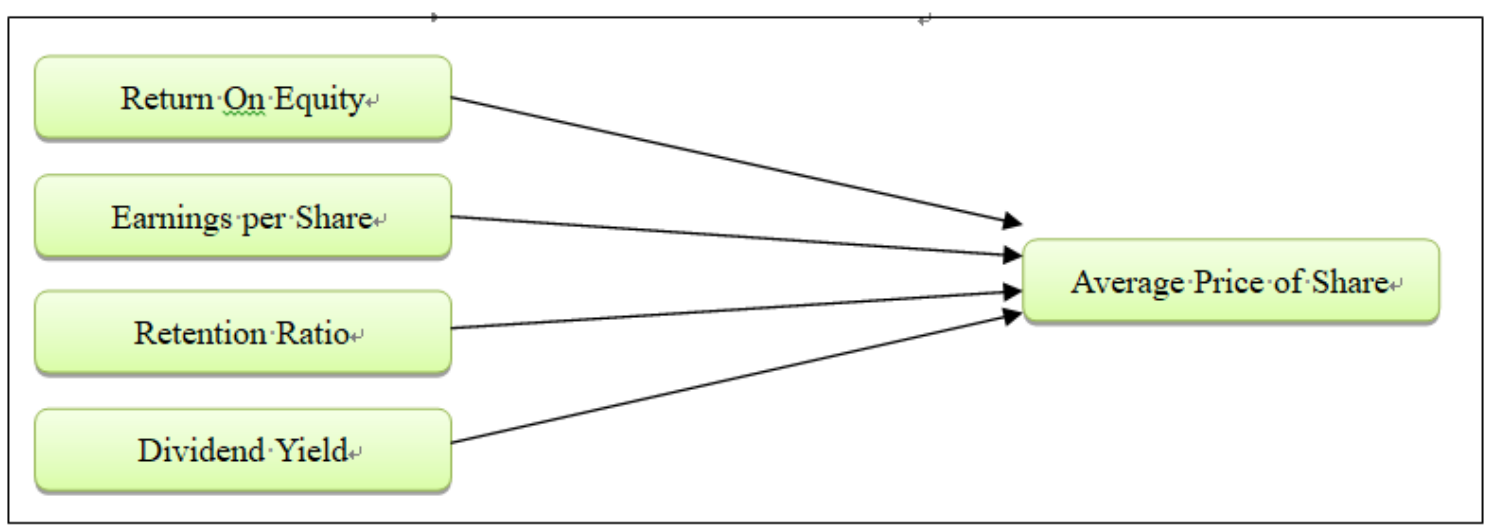

\subsection{Hypothesis}

There are four hypotheses to check the impact of dividend policy on share price volatility:

H1: There is a significant relationship between return on equity and share price.

$\mathrm{H} 2$ : There is a significant relationship between earning per share and share price.

H3: There is a significant relationship between retention ratio and share price.

H4: There is a significant relationship between dividend yield and share price.

\section{Methodology}

The basic purpose of this relationship is to find whether the dividend policy affect the share market price. The relationship between dividend policy and stock price volatility has been analyzed by using multiple regressions and correlation analysis was done amongst variables. This study was evaluated on seventeen commercial banks listed in Pakistan Stock Exchange (PSE) over the period of four years from 2014 - 2017. The selection of this period due to constrained by some factors, such as the availability of data concerned research period. In this study, we only concentrated on the banks that have been listed in PSE subject to availability of required data. Panel data methodology is used to study the impact of dividend policy on company performance (Market value) of the banking industry.

\subsection{Econometric Model}

Following regression model was developed to analyze the data

$$
\mathrm{SP}=\beta 0+\beta 1(\mathrm{DY})+\beta 2 \text { (retr) }+\beta 3 \text { (eps) }+\beta 4(\text { Roe })+\epsilon
$$

Here Sp stands for the stock price, DY stands for dividend yield, rear stand for retention ratio, eps stand for earning per share and roe stand for return on equity.

\section{Empirical Results and Discussion}

\subsection{Descriptive Statistics}

Table 1 shows the descriptive statistics of commercial banks of Pakistan data set for the time period 2014 to 2017 in terms of minimum value, maximum value, standard deviations and 
mean. The statistics show that the mean value for return and equity is 13.79 approximately. This value shows that shareholders of thirty listed commercial banks earn a return on their investment of $13.79 \%$ and the highest and lower return are $24.18 \%$ and $-1.27 \%$ respectively and this means that listed commercial banks generate $13.79 \%$ profit invested by the shareholders.

The maximum value of dividend yield is $12.96 \%$ and the minimum value is .000 with the mean value of $5.90 \%$ and the std deviation of dividend yield is 3.960584 . The maximum value of retention ration is $100 \%$ and the minimum value is .00 with the mean value of $55 \%$ approximately and std deviation of retention ration is 31.41378 . The maximum value of earning per share is 24.18 and minimum value is- 1.27 with the mean value of $6.88 \%$ and std deviation of earning per share is $7.14 \%$. The maximum value of the average price of a share is $273.58 \%$ and the minimum value is 2.14 with the mean value of $63.75 \%$ and std deviation of the average price of a share is $76.47 \%$.

Table 1. Descriptive statistics

\begin{tabular}{llllll}
\hline & $\mathrm{N}$ & Minimum & Maximum & Mean & Std. deviation \\
\hline Average price of share & 68 & 2.14 & 273.58 & 63.7529 & 76.47782 \\
Dividend yield & 68 & .000 & 12.960 & 5.89882 & 3.960584 \\
Retention ratio & 68 & .00 & 100 & 54.5009 & 31.41378 \\
Earnings per share & 68 & -1.27 & 24.18 & 6.8757 & 7.14355 \\
Return on equity & 68 & -11.170 & 20.940 & 13.78809 & 5.552342 \\
\hline
\end{tabular}

\subsection{Pearson Correlation Analysis}

The correlation analysis shows that dividend yield (DY) and retention ratio (RETR) is negatively perfect correlate with each other $(\mathrm{r}=-.815, \mathrm{p}<0.01)$. The dividend yield (DY) and return on equity (ROE) is positively moderate correlate with each other $(r=.369, p<0.01)$. There is a connection between dividend yield (DY), earning per share (EPS) and stock price (SP) with the value of $(\mathrm{r}=0.236, \mathrm{r}=0.154)$ respectively. The connection between retention ratio (RETR), earnings per share (EPS) and stock price (SP) is negatively moderate correlate with each other $(\mathrm{r}=-.365, \mathrm{p}<0.01 ; \mathrm{r}=-.424, \mathrm{p}<0.01)$ respectively. The connection between retention ratio (RETR) and return on equity (ROE) is negatively small correlate with each other $(\mathrm{r}=-.293, \mathrm{p}<0.05)$. Earning per share (EPS), return on equity (ROE) and stock price (SP) is positively strong and perfectly correlate with each other $(\mathrm{r}=.508, \mathrm{p}<0.01 ; \mathrm{r}=.918, \mathrm{p}<0.01)$ respectively. Return on equity (ROE) and stock price (SP) is positively moderate correlate with each other $(r=.337, \mathrm{p}<0.01)$. 
Table 2. Correlation matrix

\begin{tabular}{llllllll}
\hline & & & DY & Retr & EPS & ROE & SP \\
\cline { 2 - 8 } 1 & Dividend Yield & Pearson Correlation & 1 & & & & \\
2 & Retention Ratio & Pearson Correlation & $-.815^{* *}$ & 1 & & & \\
3 & Earnings Per Share & Pearson Correlation & 0.236 & $-.365^{* *}$ & 1 & & \\
4 & Return On Equity & Pearson Correlation & $.369^{* *}$ & $-.293^{*}$ & $.508^{* *}$ & 1 & \\
5 & Stock price & Pearson Correlation & 0.154 & $-.424^{* *}$ & $.918^{* *}$ & $.337^{* *}$ & 1 \\
\hline
\end{tabular}

**Correlation is significant at the 0.01 (2-tailed).

*Correlation is significant at the 0.05 (2-tailed).

\subsection{Regression Analysis}

As shown in the table dividend yield has a significant negative impact on the stock price which indicates that one-unit increase in dividend yield will cause a decrease in the stock price by 6.944 units on average by remaining all other factors constant. And the one-unit increase in retention ratio will also decrease the stock market price by 1.019 and one-unit increase in earnings per share will increase the stock price by 9.741 units on average by remaining all other factors constant. Eps show a highly significant positive effect on the firm stock price of a share in the market. Return on equity also shows a significant negative impact on the share price by a one-unit increase in the return on equity the share price will be reduced by 1.586 on average by remaining all other factors constant.

Table 3. Regression analysis

\begin{tabular}{lllll}
\hline SP & Coef & Std. err & $\mathrm{z}$ & $\mathrm{p}$ \\
\hline DY & -6.944375 & 1.220111 & -5.69 & 0.000 \\
RETR & -1.018813 & .1546851 & -6.59 & 0.000 \\
EPS & 9.741137 & .4581909 & 21.26 & 0.000 \\
ROE & -1.586481 & .586734 & -2.70 & 0.007 \\
CONS & 115.1398 & 15.66514 & 7.35 & 0.000 \\
\hline
\end{tabular}

\section{Conclusion}

The purpose of this research was to find the relationship between dividend policy and share price volatility and our empirical analysis results show that dividend policy affects share price and all the variable of our study shows the significant impact. We will accept all hypotheses because our results show that there is a relationship between all the dependent variable and independent variable. Earnings per share show a significant positive impact on the share market price and all other independent variable dividend yields, return on equity and retention ratio shows a significant but negative impact on the share price.

The empirical findings suggest that there is a negative relationship between dividend yield and stock price volatility. Our results matched with the findings of (Allen \& Rachim, 1996). Our research finding is also consistent with the finding of Noor Ahmed Memon, Dr. Nizamuddin Channa and Dr. Imamuddin Khoso (2017) their results show the relationship 
between dividend yield and stock price but these two variables are correlated negatively. Our research finding also support the research results of Abdullah Al Masum (2014) he found that retention ratio has an empirically significant but negative impact on the stock market price of banks listed at Dhaka stock exchange and our finding also shows that retention ratio and stock price has a significant negative relation of banks listed at Pakistan stock exchange.

\section{References}

Al Shabibi, Badar, K., \& Ramesh, G. (2011). An Empirical Study on the Determinants of Dividend Policy in the UK. International Research Journal of Finance and Economics, 80(12), 105-24.

Allen, D. E., \& Veronica, S. R. (1996). Dividend Policy and Stock Price Volatility: Australian Evidence. Applied Financial Economics, 6(2), 175-88. https://doi.org/10.1080/ 096031096334402

Amidu, M., \& Joshua, A. (2006). Determinants of Dividend Payout Ratios in Ghana. The Journal of Risk Finance, 7(2), 136-45. https://doi.org/10.1108/15265940610648580

Baskin, J. (1989). An Empirical Investigation of the Pecking Order Hypothesis. Financial Management, 18(1), 26-35. https://doi.org/10.2307/3665695

Bhattacharya, S. (1979). Imperfect Information, Dividend Policy, and 'the Bird in the Hand' Fallacy. Bell Journal of Economics, 10(1), 259-70. https://doi.org/10.2307/3003330

Black, F. (1976). Stuedies of Stock Price Volatility Changes, 177-81.

Chijoke - Mgbame, A. M., Khaled, H., \& Chijoke, O. M. (2011). Dividend Policy and Share Price Volatility: UK Evidence. The Journal of Risk Finance, 12(1), 57-68. https://doi.org/10.1108/15265941111100076

DeAngelo, H., Linda, D., \& Douglas, J. S. (1996). Reversal of Fortune Dividend Signaling and the Disappearance of Sustained Earnings Growth. Journal of Financial Economics, 40(3), 341-71. https://doi.org/10.1016/0304-405X(95)00850-E

Elfakhani, S., \& Mohammed, C. (1995). The Volatility Effect of Option Listing: Some Canadian Evidence. The Quarterly Review of Economics and Finance, 35(1), 97-116. https://doi.org/10.1016/1062-9769(95)90065-9

Fama, E. F., \& Kenneth, R. F. (2001). Disappearing Dividends: Changing Firm Characteristics or Lower Propensity to Pay? Journal of Financial Economics, 60(1), 3-43. https://doi.org/10.1016/S0304-405X(01)00038-1

Franco, M. (1988). MM-Past, Present, Future. Journal of Economic Perspectives, 2(4), 149-158. https://doi.org/10.1257/jep.2.4.149

Gordon, M. J. (1959). Dividends, Earnings, and Stock Prices. The Review of Economics and Statistics, 41(2), 99-105. https://doi.org/10.2307/1927792

Gordon, M. M. (1961). Assimilation in America: Theory and Reality. Daedalus, 90(2), 263-85.

Jo, H., \& Carrie, P. (2009). Why Are Firms with Entrenched Managers More Likely to Pay Dividends? Review of Accounting and Finance, 8(1), 87-116. https://doi.org/10.1108/ 14757700910934256

Jones, C., \& John, W. (1999). Too Much of a Good Thing? The Economics of Investment in 
R\&D. Cambridge, MA: National Bureau of Economic Research. https://doi.org/10.3386/w7283

Khalique, M., Nick, B., Jamal, A. N. S., \& Abu, Ha. Md. I. (2015). Intellectual Capital in Small and Medium Enterprises in Pakistan. Journal of Intellectual Capital, 16(1), 224-38. https://doi.org/10.1108/JIC-01-2014-0014

Lee, Y-T., Yu-Jane, L., Richard, R., \& Avanidhar, S. (2006). Taxes and Dividend Clientele: Evidence from Trading and Ownership Structure. Journal of Banking \& Finance, 30(1), 229-46. https://doi.org/10.1016/j.jbankfin.2005.03.009

Lintner, J. (1956). Distribution of Incomes of Corporations Among Dividends, Retained Earnings, and Taxes. The American Economic Review, 46(2), 97-113.

Michaely, R., Richard, H. T., \& Kent, L. W. (1995). Price Reactions to Dividend Initiations and Omissions: Overreaction or Drift? The Journal of Finance, 50(2), 573-608. https://doi.org/10.1111/j.1540-6261.1995.tb04796.x

Miller, M. H. (2002). Selected Works of Merton H. Miller: A Celebration of Markets (Volume 1: Finance). University of Chicago Press.

Modigliani, F. (1982). Debt, Dividend Policy, Taxes, Inflation and Market Valuation. The Journal of Finance, 37(2), 255-73. https://doi.org/10.1111/j.1540-6261.1982.tb03549.x

Nizar, Al - Malkawi, \& Husam - Aldin. (2007). Determinants of Corporate Dividend Policy in Jordan: An Application of the Tobit Model. Journal of Economic and Administrative Sciences, 23(2), 44-70. https://doi.org/10.1108/10264116200700007

Okafor, C. A., \& Chijoke-Mgbame, A. M. (2011). Dividend Policy and Share Price Volatility in Nigeria. JORIND, 9, 202-10.

Shiller, R. J. (1989). Comovements in Stock Prices and Comovements in Dividends. The Journal of Finance, 44(3), 719-29. https://doi.org/10.1111/j.1540-6261.1989.tb04387.x

Wu, W-Y., Man-Ling, C., \& Chih-Wei, C. (2008). Promoting Innovation through the Accumulation of Intellectual Capital, Social Capital, and Entrepreneurial Orientation. $R \& D$ Management, 38(3), 265-77. https://doi.org/10.1111/1467-9914.00120-i1

Iqbala, F., Ah, M. B., Ahmadb, M. B., \& Ali, H. F. Determinants of Capital Structure: A Pakistan.

\section{Copyright Disclaimer}

Copyright for this article is retained by the author(s), with first publication rights granted to the journal. This is an open-access article distributed under the terms and conditions of the Creative Commons Attribution license (http://creativecommons.org/licenses/by/3.0/). 